\title{
Pituitary Adenylate Cyclase-Activating Polypeptide and Sonic Hedgehog Interact to Control Cerebellar Granule Precursor Cell Proliferation
}

\author{
Arnaud Nicot,, ${ }^{1}$ Vincent Lelièvre, ${ }^{2}$ Jimmy Tam, ${ }^{2}$ James A. Waschek, ${ }^{2 *}$ and Emanuel DiCicco-Bloom ${ }^{1,3 *}$ \\ ${ }^{1}$ Department of Neuroscience and Cell Biology, University of Medicine and Dentistry of New Jersey/Robert Wood \\ Johnson Medical School, Piscataway, New Jersey 08854, ²Department of Psychiatry, Mental Retardation Research \\ Center, University of California, Los Angeles, Los Angeles, California 90024, and ${ }^{3}$ Department of Pediatrics, University of \\ Medicine and Dentistry of New Jersey/Robert Wood Johnson Medical School, New Brunswick, New Jersey 08901
}

Although positive and negative signals control neurogenesis in the embryo, factors regulating postnatal proliferation are less well characterized. In the vertebrate cerebellum, Sonic Hedgehog (Shh) is an efficacious mitogen for cerebellar granule neuron precursors (GNPs), and mutations activating the Shh pathway are linked to medulloblastoma, a tumor derived from GNPs. Although the mitogenic effects of Shh can be blocked by increasing CAMP or protein kinase A activity, the physiological factors antagonizing this stimulation are undefined. In the embryo, pituitary adenylate cyclase-activating polypeptide (PACAP) receptor 1 (PAC1) signaling regulates neural precursor proliferation. We now show that in the developing cerebellum, PAC1 mRNA colocalizes with gene transcripts for Shh receptor Patched 1 and target gene Gli1 in the external germinal layer. We consequently investigated the interactions of PACAP and Shh in proliferation of purified GNPs in culture. Shh exhibited mitogenic activity in both rat and mouse cultures, stimulating
DNA synthesis $\sim 10$-fold after $48 \mathrm{hr}$ of exposure. PACAP markedly inhibited Shh-induced thymidine incorporation by 50 and $85 \%$ in rat and mouse GNPs, respectively, but did not significantly affect the stimulation induced by other mitogens. This selective effect was reproduced by the specific PAC1 agonist maxadilan, as well as by the adenylate cyclase activator forskolin, suggesting that PAC1 provides a potent inhibitory signal for Shh-induced proliferation in developing cerebellum. In contrast, in the absence of Shh, PACAP and maxadilan modestly stimulated DNA synthesis, an effect reproduced by activating protein kinase C. These observations suggest that G-proteincoupled receptors, such as PAC1, serve as sensors of environmental cues, coordinating diverse neurogenetic signals.

Key words: neurogenesis; cerebellum; neuronal precursors; GPCR; serpentine receptors; neuropeptide; proliferation; medulloblastoma
During the first two postnatal weeks in rodent cerebellum, granule neuron precursor (GNP) cells proliferate in the external germinal cell layer (EGL) and migrate past Purkinje neurons to form the internal granule cell layer (IGL), where they mature into granule neurons (Altman and Bayer, 1996). The EGL precursors themselves originate prenatally from the roof of the fourth ventricle, in the rhombic lip (Alder et al., 1996). Although the sequence of cerebellar development is well described, the molecular mechanisms governing the GNP shift from proliferation to differentiation are not well characterized. Purkinje neurons apparently control granule cell number by regulating GNP expansion (Smeyne et al., 1995) and by providing trophic support for mature granule neurons (Vogel et al., 1989). Sonic Hedgehog (Shh), which is produced by Purkinje neurons, is an important mitogen for GNPs (Dahmane and Ruiz-i-Altaba, 1999; Wallace, 1999; Wechsler-Reya and Scott, 1999). Indeed, mutations that

\footnotetext{
Received July 10, 2002; revised July 10, 2002; accepted Aug. 12, 2002.

This work was supported by National Institutes of Health Grants HD06576, HD34475, and HD0461 (J.A.W.) and NS 32401 (E.D.-B.) and The Children's Brain Tumor Foundation (E.D.-B.). E. D.-B. is a member of the Cancer Institute of New Jersey, National Institute of Environmental Health Sciences/United States Environmental Protection Agency Center for Childhood Neurotoxicology and Assessment.

$*$ J.A.W. and E.D.-B. contributed equally to this work.

Correspondence should be addressed to Dr. Arnaud Nicot, Department of Neuroscience and Cell Biology, University of Medicine and Dentistry of New Jersey/ Robert Wood Johnson Medical School, 675 Hoes Lane, CABM Room 338, Piscataway, NJ 08854. E-mail: nicotar@umdnj.edu.

Copyright (C) 2002 Society for Neuroscience 0270-6474/02/229244-11\$15.00/0
}

activate the Hedgehog pathway contribute to the formation of medulloblastoma, a human tumor likely derived from granule cell precursors (for review, see Wechsler-Reya and Scott, 2001). Shh binds to a receptor complex composed of the transmembrane proteins Patched (Ptc) and Smoothened (Smo) (Marigo et al., 1996; Stone et al., 1996), which are expressed by GNPs (Traiffort et al., 1999), leading to the activation of transcriptional targets (Ruiz i Altaba, 1999). Although Shh responses can be antagonized by increasing cAMP levels and PKA activity (Fan et al., 1995; Hammerschmidt et al., 1996), extracellular signals increasing cAMP and inhibiting Shh action remain undefined. The neuropeptide pituitary adenylate cyclase-activating polypeptide (PACAP), which regulates cAMP (Harmar et al., 1998), may be one such factor, because it provides antimitogenic activity for prenatal hindbrain and cortical neuroblasts ( $\mathrm{Lu}$ and DiCiccoBloom, 1997; Waschek et al., 1998; Suh et al., 2001), although mitogenic effects in the developing cerebellum, especially postnatal neurogenesis, are unknown.

PACAP belongs to a peptide family that includes secretin, glucagon, growth hormone-releasing factor, and vasoactive intestinal peptide (VIP) and interacts via three G-protein-coupled receptors (Harmar et al., 1998); VPAC1 and VPAC2 have high affinity for both VIP and PACAP, whereas PACAP receptor 1 (PAC1) binds only PACAP with high affinity. Activation of the three PACAP receptors typically leads to a robust $\mathrm{G}_{\mathrm{s}}$-mediated cAMP elevation, whereas PAC1 can also link to other transduc- 
tion pathways, such as phospholipase C (PLC) and calcium mobilization (Arimura, 1998). In previous studies, differential pathway activation has been linked to different PAC1 splice isoforms (Spengler et al., 1993; Chatterjee et al., 1996; Nicot and DiCiccoBloom, 2001).

The presence of PACAP ligand and receptors during the first 2 postnatal weeks in rodents suggests a role for PACAP in cerebellar neurogenesis (Nielsen et al., 1998; Skoglosa et al., 1999; Basille et al., 2000; Jaworski and Proctor, 2000). Although PACAP promotes granule cell survival (Cavallaro et al., 1996; Gonzalez et al., 1997; Villalba et al., 1997; Vaudry et al., 1999), its effects on GNP mitotic activity are undefined. Here, we show that PAC1 receptors are expressed by granule precursors coincident with gene transcripts for Ptc1 and target gene Gli1. Furthermore, we identify context-dependent mitogenic actions of PACAP and potent inhibition of Shh-induced mitogenic signaling in cultured GNPs.

\section{MATERIALS AND METHODS}

In situ hybridization. Frozen brains were sectioned sagittally at $10-12 \mu \mathrm{m}$ thickness, mounted on Superfrost Plus slides (Fisher Scientific, Houston, $\mathrm{TX}$ ), and then stored at $-70^{\circ} \mathrm{C}$ until use. Sense and antisense ${ }^{33} \mathrm{P}$-labeled riboprobes were prepared from linearized plasmids containing cDNAs for the rat PAC1 receptor (Pisegna and Wank, 1993), mouse gli1 (1.6 kb EcoRI fragment from Dr. A. Joyner, New York University, New York, NY), mouse ptc1 (M2-3 containing 841 bp EcoRI fragment from Dr. M. Scott, Stanford University, Stanford, CA), and mouse sonic hedgehog (642 bp Eco RI fragment, cloned into pBluescript II SK, provided by Dr. A. McMahon, Harvard University, Cambridge, MA) (Echelard et al., 1993). In situ detection was performed as described previously (Waschek et al., 1998). Slides were dipped in Kodak NTB2 emulsion (Rochester, NY). After development, slides were examined with a Zeiss Axiovert 135M microscope equipped with the Spot Cooled Color Digital Camera (Diagnostic Instruments, Sterling Heights, MI).

Reverse transcription-PCR. Reverse transcription (RT) reactions were performed using $0.5 \mu \mathrm{g}$ of total RNA per reaction and the Retroscript RT-PCR kit (Ambion, Austin, TX). The conditions for detection of PAC1 mRNA splice isoforms and for VPAC1 and VPAC2 mRNAs were identical to those described previously (Lelievre et al., 2002). Primer sets were designed to recognize both rat and mouse receptor sequences with 35 cycles of amplification. The primer sequences were the following: For PAC1: sense, GGATGCTGGGATATGAATGACAGCACAGC, which recognized the sequences 1035-1064 and 1027-1035 of the mouse and rat cDNAs, respectively (GenBank accession numbers D82935 and D14909); reverse, CCTTCCAGCTCCTCCATTTCCTCT, which recognized the sequences $1495-1472$ and $1466-1452$ of the same cDNAs. For VPAC1: sense, CGGAAGTACTTCTGGGGGTAC, which recognized the sequences 757-777 and 765-785 of the mouse and rat cDNAs, respectively (GenBank accession numbers MN011703 and MN012685); reverse, CCTGCAGATGCCAACGCCGCCAC, which recognized specifically the regions $1234-1212$ and $1242-1220$ of the same cDNAs. For VPAC2: sense, GCCTGGTATTCTTCCAGTACTG, which recognized the sequences 663-684 and 726-747 of mouse and rat VPAC2 receptor cDNAs, respectively (GenBank accession numbers NM009511 and NM017238); reverse, CAGTTCACGCTGTACCTCACTG, which corresponded to the sequences 1207-1186 and 1270-1249 of the same cDNAs. To confirm the specificity of the DNA amplifications, Southern blot analyses were undertaken using $\left[{ }^{32} \mathrm{P}\right]$-end-labeled specific oligonucleotides as described previously (Lelievre et al., 2002).

Granule cell isolation and cell culture. Isolation of granule cells (>98\% pure) was performed as described previously (Tao et al., 1996) from Sprague Dawley rats (Hilltops Labs, Philadelphia, PA) or mice (housed C57BL/6J $\times 129 / \mathrm{Sv})$. Cleaned rat or mouse cerebella were incubated in trypsin-DNase solution (mixture of $1 \%$ trypsin and $0.1 \%$ DNase; Worthington, Lakewood, $\mathrm{NJ}$ ) for $3 \mathrm{~min}$ and dissociated in DNase solution $(0.05 \%$ in DMEM) by trituration. After pelleting, cells were filtered (30 $\mu \mathrm{m}$ nylon mesh; Tekton, Tarrytown, NY), resuspended, and centrifuged at $3200 \mathrm{rpm}$ on a Percoll (Sigma, St. Louis, MO) 35:60\% step gradient (Hatten, 1985; Gao et al., 1991). Cells at the 35:60\% interface were collected and washed in phosphate buffer. For RT-PCR studies, RNA was obtained from isolated cells from postnatal day 5 (P5) P7, and P10 rats, using RNAqueous kit (Ambion). For cultures, cells isolated from P6 to $\mathrm{P} 7$ rats (three per experiment) or mice (six to seven per experiment) were plated onto a poly-D-lysine $(20 \mu \mathrm{g} / \mathrm{ml})$-coated $60 \mathrm{~mm}$ culture dish in defined medium (DM) composed of a 1:1 mixture of F12 and DMEM, 10 $\mathrm{ng} / \mathrm{ml}$ insulin, $100 \mu \mathrm{g} / \mathrm{ml}$ transferrin, $10 \mathrm{mg} / \mathrm{ml}$ bovine serum albumin, $100 \mu \mathrm{M}$ putrescine, $20 \mathrm{nM}$ progesterone, $30 \mathrm{~nm}$ selenium, $6 \mathrm{mg} / \mathrm{ml}$ glucose, $50 \mathrm{U} / \mathrm{ml}$ penicillin, and $50 \mu \mathrm{g} / \mathrm{ml}$ streptomycin. After $1 \mathrm{hr}$ of preplating to remove adherent flat cells (representing no more than $2 \%$ of the cells), small round (granule) cells were dislodged by gentle pipetting and plated at $\sim 2 \times 10^{5} / \mathrm{cm}^{2}$. For thymidine incorporation studies, cells were cultured in poly-D-lysine-coated 24 well plates in DM, DM plus high insulin $(5 \mu \mathrm{g} / \mathrm{ml}$, corresponding to the concentration found in classical N2 supplemented medium), DM plus B27 supplement (2\%), or DM containing $3 \mu \mathrm{g} / \mathrm{ml}(150 \mathrm{nM})$ recombinant mouse Shh-N (N indicates the N-terminal fragment; \#461-SH; R \& D Systems, Minneapolis, MN). The next day (12-16 hr later), cells were treated with vehicle, PACAP1-38 (10 nM; American Peptide, Sunnyvale, CA), maxadilan (10 nM, a gift from E. Lerner, Harvard University, Cambridge, MA), or forskolin (30 $\mu \mathrm{M}$; Sigma) for 6 or $24 \mathrm{hr}$. For RT-PCR and bromodeoxyuridine (BrdU) labeling studies, P7 rat or mouse cells were plated in poly-D-lysine-coated $35 \mathrm{~mm}$ dishes in DM or DM plus Shh-N for 24 or $48 \mathrm{hr}$.

DNA synthesis. Incorporation of $\left[{ }^{3} \mathrm{H}\right]$ thymidine $\left(\left[{ }^{3} \mathrm{H}\right] \mathrm{dT}\right)$ was used to assess DNA synthesis (DiCicco-Bloom et al., 2000). Cells were incubated with $\left[{ }^{3} \mathrm{H}\right] \mathrm{dT}$ during the final $2 \mathrm{hr}$ of incubation, and incorporation was assayed by scintillation spectroscopy. Experiments were performed two to four times, with three to four samples per group per experiment. Mean values for control and treated cultures were compared using one-way ANOVA followed by Sheffe post hoc or using Student's $t$ test when appropriate.

BrdU labeling index. To visualize cells synthesizing DNA, cells were exposed to the $\mathrm{S}$ phase marker BrdU (10 $\mu \mathrm{M}$; Sigma) during the final 4 $\mathrm{hr}$ of incubation. After fixation, cells were exposed to $2 \mathrm{~N} \mathrm{HCl}(30 \mathrm{~min})$, rinsed twice in PBS, incubated overnight in monoclonal anti-BrdU (1: 100; Dako, Carpinteria, CA) in PBS/0.3\% Triton X-100, followed by $1 \mathrm{hr}$ of incubation with a biotinylated anti-mouse secondary antibody. Staining was visualized using a Vectastain avidin-biotin complex kit and Vector SG peroxidase substrate (Vector Laboratories, Burlingame, CA). The labeling index, defined as the proportion of total cells incorporating BrdU into the nucleus, was determined by scoring the cells in five randomly selected, nonoverlapping fields in each of the two to five dishes per group per experiment.

\section{RESULTS \\ PACAP and Shh system expression during embryonic and postnatal cerebellar development}

Previously, we characterized expression of the high-affinity PACAP-preferring PAC1 receptors in the ventricular zone (VZ) throughout the mouse hindbrain at embryonic day 10.5 (E10.5) and found that PACAP inhibited DNA synthesis and Gli1 expression in cultured hindbrain precursors (Waschek et al., 1998). To determine whether the PACAP ligand/receptor system also plays a role in the developing cerebellum, in situ hybridization was performed on sagittal sections of embryonic mice. At E12.5, PAC1 gene transcripts were found to be abundant in the emerging rhombic lip (Fig. $1 A$ ), which later expands to become the EGL. In contrast, PAC1 gene transcripts were expressed at low levels or were absent in the cerebellar plate VZ, which gives rise to Purkinje cells and, at later times, to several other neural cell types. However, PAC1 gene expression was clearly detected in both cerebellar germinal centers $2 \mathrm{~d}$ later (Fig. $1 B, C$ ). In contrast to receptor transcripts, PACAP expression was prominent in the lateral cerebellar primordium, adjacent to the $\mathrm{VZ}$ and rhombic lip (Fig. $1 D, E$ ). From this location, PACAP might signal to GNPs to regulate their development, although effects on other precursors would also be possible.

One possible action of PACAP on GNPs is to regulate their proliferation. At birth, the EGL consists of a multicell layer of undifferentiated precursors that undergo extensive proliferation, 
Figure 1. PAC1 receptor and PACAP ligand gene expression during embryonic development detected by in situ hybridization. $A$, Bright-field micrograph showing PAC1 gene expression in the hindbrain ventricular zone and rhombic lip $(R L)$ but absent in the cerebellar plate $(C b P)$ in a sagittal section from an E12.5 mouse. Scale bar, $1 \mathrm{~mm} . B, C$, Micrographs showing PAC1 gene expression in E14.5 hindbrain and cerebellar area sagittal sections. $B$, Bright field; $C$, corresponding dark field. Scale bars, $500 \mu \mathrm{m}$. $D, E$, In situ hybridizations (bright fields) showing PACAP gene expression in a transverse hemisection at the level of the cerebellar primordium at E14.5. E, Higherpower micrograph from the box in $D$. Scale bars: $D, 500 \mu \mathrm{m} ; E, 25 \mu \mathrm{m}$. No significant hybridization signals were seen with sense probes. $C b P$, Cerebellar plate; $C b P r$, cerebellar primordium; $C P$, choroid plexus; $I s$, isthmus;
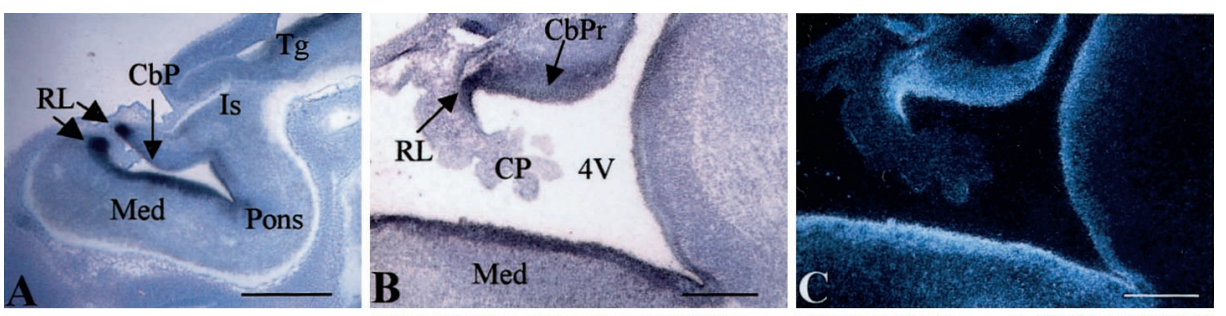

$L R$, lateral recess of fourth ventricle; $M e d$, medulla; $R L$, rhombic lip; $T g$, tegmentum; $4 V$, fourth ventricle.

generating a large precursor pool during the next few days. To define possible functions in postnatal neurogenesis, PAC1 gene transcript expression in the EGL was compared with localization of the Shh receptor Ptc1 and the target gene Gli1. At P1, GNPs are located in the EGL, whereas relatively few cells have migrated past the Purkinje neurons to form the IGL. Ptc1 and Gli1 gene transcripts were highly expressed in both the EGL and presumptive Purkinje layer (Fig. $2 A / D, B / E$ ), as shown by others (Dahmane and Ruiz-i-Altaba, 1999; Traiffort et al., 1999; Wallace, 1999). PAC1 gene transcripts also exhibited intense expression in the EGL on P1 (Fig. $2 C / F$ ), suggesting possible interactions. During subsequent postnatal development, Purkinje cells express increasing levels of Shh (Traiffort et al., 1999) as granule precursors undergo extensive proliferation (Altman and Bayer, 1996). Concurrently, postmitotic differentiating granule neurons migrate from the inner EGL (iEGL) to the IGL. Expression studies support continuing factor interactions as neurogenesis increases at P6-P7, because Ptc1 (Fig. 3C), Gli1 (Fig. 3D), and PAC1 (Fig. 3E) transcripts remain colocalized in the EGL. However, although Ptc1 hybridization signal is uniformly localized in both the outermost part of the EGL (oEGL) and the iEGL, the Gli1 hybridization signal is more intense in the oEGL, as reported previously (Traiffort et al., 1999), whereas the PAC1 hybridization signal is most abundant in iEGL, raising the possibility of sequential or opposing functions. Finally, PACAP gene expression was detected diffusely in the Purkinje layer and more strongly in deep cerebellar nuclei (data not shown), as reported previously (Nielsen et al., 1998; Skoglosa et al., 1999). Because both PAC1 and Shh receptors are colocalized in the postnatal EGL, cognate ligand interactions may coordinate GNP proliferation.

\section{Comparison of PACAP receptors in cerebellar populations}

Because PACAP may activate PAC1, VPAC1, and VPAC2, the occurrence of mRNAs for these receptors was investigated by RT-PCR followed by Southern blot in freshly isolated granule cells (lower phase of the gradient; see Materials and Methods) and was compared with cells in the upper phase of the gradient (mostly glia and Purkinje cells). Both mice and rats expressed mRNAs for PAC1 receptor, primarily short (null) and hop isoforms (the hip isoform was barely detected by Southern blot) in granule and glial/Purkinje cells (Fig. 4). VPAC1 and VPAC2 mRNAs were also expressed in both phases in rats and mice with the signals appearing much less intense in granule cells (Fig. 4, bottom panels). These patterns of receptor gene expression in isolated granule cells did not change appreciably in P5, P7, or P10 animals (data not shown), suggesting that the PACAP-selective PAC1 receptor is the predominant response system in GNPs during postnatal neurogenesis.

\section{Proliferative activity of mouse and rat cerebellar neuroblasts: effects of medium composition}

Although the foregoing expression studies suggest that PACAP signaling may regulate both prenatal and postnatal granule cell production, we focused on postnatal development because isolated granule precursors from P6 to P7 rodents serve as a well characterized model to define regulatory mechanisms. Before examining PACAP and Shh interactions, we investigated the effects of defined media and components on precursor mitosis, thereby allowing comparison with diverse previous studies. Although most studies of Shh were performed on mouse cerebellar cells in media containing B27 or N2 supplements (Dahmane and Ruiz-i-Altaba, 1999; Wallace, 1999; Wechsler-Reya and Scott, 1999; Kenney and Rowitch, 2000), the actions of PACAP have been defined in rat cultures in N2 or serum-supplemented media (Gonzalez et al., 1997; Villalba et al., 1997; Vaudry et al., 1999). To compare directly mitotic activity in different media, both mouse and rat P6-P7 cerebellar GNPs were incubated for 24-48 $\mathrm{hr}$ in defined medium containing only low insulin $(10 \mathrm{ng} / \mathrm{ml}$, a concentration with metabolic but not mitogenic activity) (DM), DM supplemented with high insulin $(5 \mu \mathrm{g} / \mathrm{ml}$, the concentration present in N2 media), DM containing B27 supplement, or DM supplemented with Shh. In contrast to most previous studies examining PACAP (Gonzalez et al., 1997; Villalba et al., 1997; Vaudry et al., 1999) or Shh (Kenney and Rowitch, 2000; Klein et al., 2001; Pons et al., 2001; Solecki et al., 2001), we did not use 20-25 mM KCl, because KCl-induced depolarization inhibits basal proliferation of cerebellar precursors (Cui and Bulleit, 1998) and induces PACAP expression in differentiating cells (Tabuchi et al., 2001). Furthermore, we found that in serum-free media, $\mathrm{KCl}$ addition was not required to support survival, at least for $3 \mathrm{~d}$, confirming previous results (Kingsbury et al., 1985). We measured $\left[{ }^{3} \mathrm{H}\right] \mathrm{dT}$ incorporation as a marker of DNA synthesis (Fig. 5). In all conditions, mouse GNPs exhibited fourfold to 10 -fold less mitotic activity compared with rat cells when plated at equivalent cell number. The addition of high concentrations of insulin $(5 \mu \mathrm{g} / \mathrm{ml})$, which stimulate insulin-like growth factor-I (IGF-I) receptors, elicited a fourfold to 10 -fold increase in 

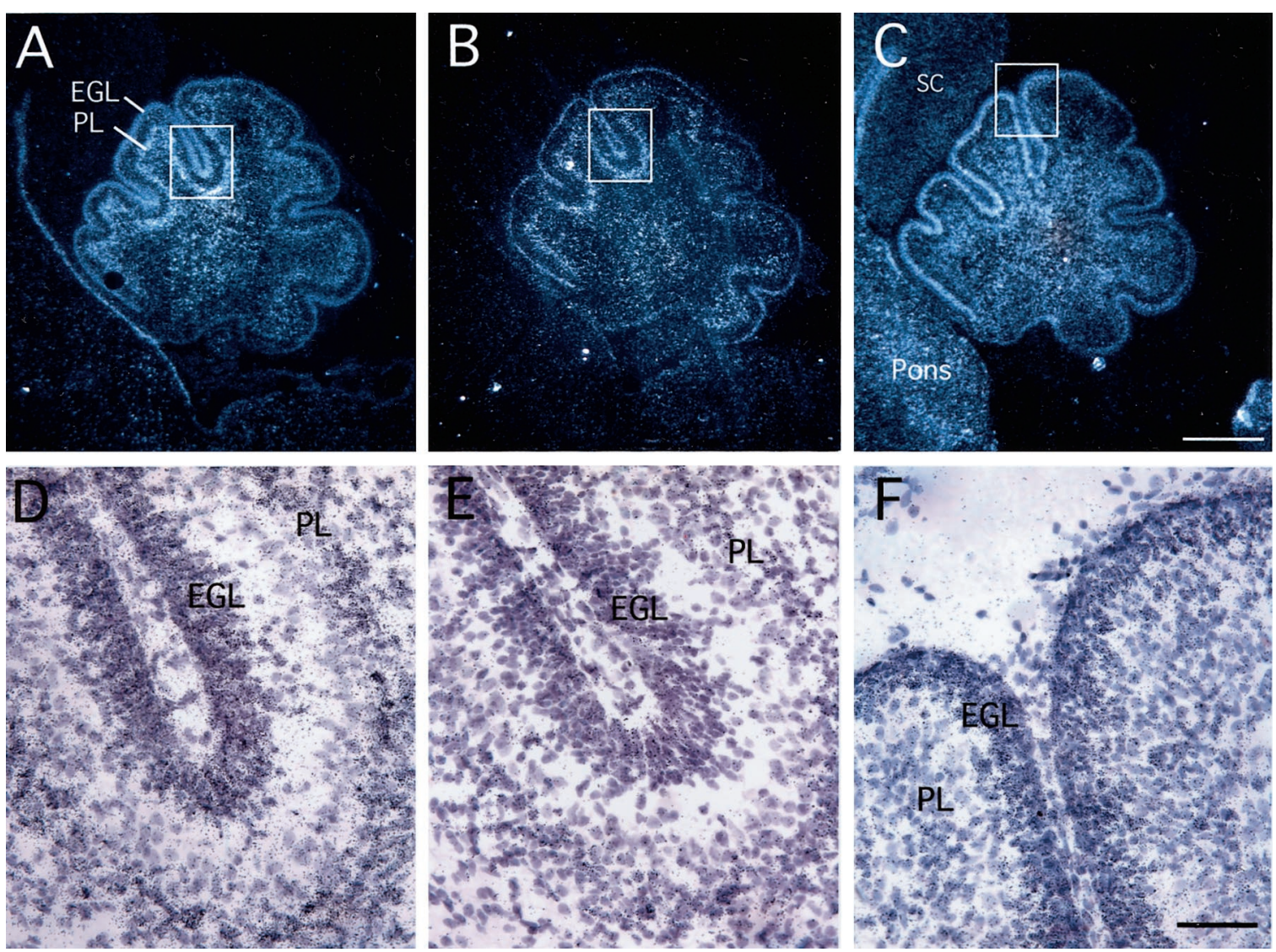

Figure 2. Localization of Ptc1 $(A, D)$, Gli1 $(B, E)$, and PAC1 $(C, F)$ gene expression in postnatal day 1 rat brain by in situ hybridization. Dark-field photomicrographs of sagittal sections of cerebellum are shown in $A-C$ (scale bar, $500 \mu \mathrm{m}$ ). Bright-field views of corresponding boxes at higher magnification are shown in $D-F$ (scale bar, $50 \mu \mathrm{m}$ ). PL, Purkinje cell layer; $S C$, spinal cord.

$\left[{ }^{3} \mathrm{H}\right] \mathrm{dT}$ incorporation at $1 \mathrm{~d}$ in vitro (DIV1), consistent with the trophic and proliferative effects of IGF-I in various neuroblast populations, including cerebellar granule cells (DiCicco-Bloom et al., 1989; Gao et al., 1991; D’Mello et al., 1993; Ye et al., 1996; Lin and Bulleit, 1997). Basal GNP mitotic activity in B27containing medium was even more pronounced, likely reflecting the actions of mitogenic hormones, such as retinoic acid (Wohl and Weiss, 1998) and thyroid hormone T3 (Lezoualc'h et al., 1995), that are present in this supplement (Brewer, 1995). However, after sustained exposure (48 hr, DIV2), effects were reduced, consistent with differentiation induction by IGF-I or B27 supplements (Brewer, 1995; Morrione et al., 2000; Niblock et al., 2000). In marked contrast, although initial effects were modest, Shh alone provided sustained mitogenic activity from DIV1 to DIV2; Shh produced 2.5-fold and $\sim 10$-fold increases in DNA synthesis at DIV1 and DIV2, respectively, in agreement with previous reports (Wechsler-Reya and Scott, 1999).

\section{PACAP differentially regulates DNA synthesis in GNP cultures}

To define the effects of PACAP on DNA synthesis, we analyzed $\left[{ }^{3} \mathrm{H}\right] \mathrm{dT}$ incorporation in cells exposed to PACAP for 6 and $24 \mathrm{hr}$. We used the $6 \mathrm{hr}$ paradigm to better identify mitogenic signals separate from possible trophic activity. Specifically, because little cell death occurs in just $6 \mathrm{hr}$, survival-promoting activity cannot be observed. Therefore, increases in DNA synthesis and in the proportion of cells exhibiting BrdU nuclear labeling primarily reflect progression from $\mathrm{G}_{1}$ into $\mathrm{S}$ phase (Lu et al., 1996; Lu and DiCicco-
Bloom, 1997). In contrast, $24 \mathrm{hr}$ of treatment allows assessment of prolonged and/or cumulative effects on proliferation.

To facilitate comparisons of the effect of PACAP in the presence of different mitogens, we normalized data to the percentage of the vehicle control response, although groups receiving only vehicle exhibit different baseline incorporation (Fig. 6E) as reported above (Fig. 5). In the $6 \mathrm{hr}$ paradigm, PACAP elicited a modest $(20-30 \%)$ increase in $\left[{ }^{3} \mathrm{H}\right] \mathrm{dT}$ incorporation in DM (no mitogen), DM plus high insulin, or DM plus B27 supplements in rat cultures (Fig. 6A), whereas it had no significant effect in mouse GNP cultures (Fig. $6 B$ ). The fact that we detected consistent increases in thymidine incorporation as soon as $6 \mathrm{hr}$ after PACAP addition suggests that PACAP exerts mitotic activity. To confirm this, we analyzed cell numbers and performed BrdUlabeling experiments after $6 \mathrm{hr}$ of PACAP treatment (Fig. 7). PACAP increased the BrdU labeling index by $32 \%$ in the absence of altered cell numbers, indicating that the peptide did not promote survival of cells possibly undergoing cell death. Rather, increased thymidine incorporation (Fig. 6A) reflected more cells entering $\mathrm{S}$ phase. This increased $\mathrm{G}_{1}$ to $\mathrm{S}$ phase progression is consistent with direct mitogenic activity. However, this effect does not seem to be to sufficient to sustain proliferation, as indicated by diminished incorporation observed after longer PACAP treatment (Fig. 6C).

In marked contrast, in medium containing Shh, $6 \mathrm{hr}$ of treatment with PACAP inhibited DNA synthesis by $20-30 \%$ in both species (Fig. 6A,B). Furthermore, the decrease was even more 

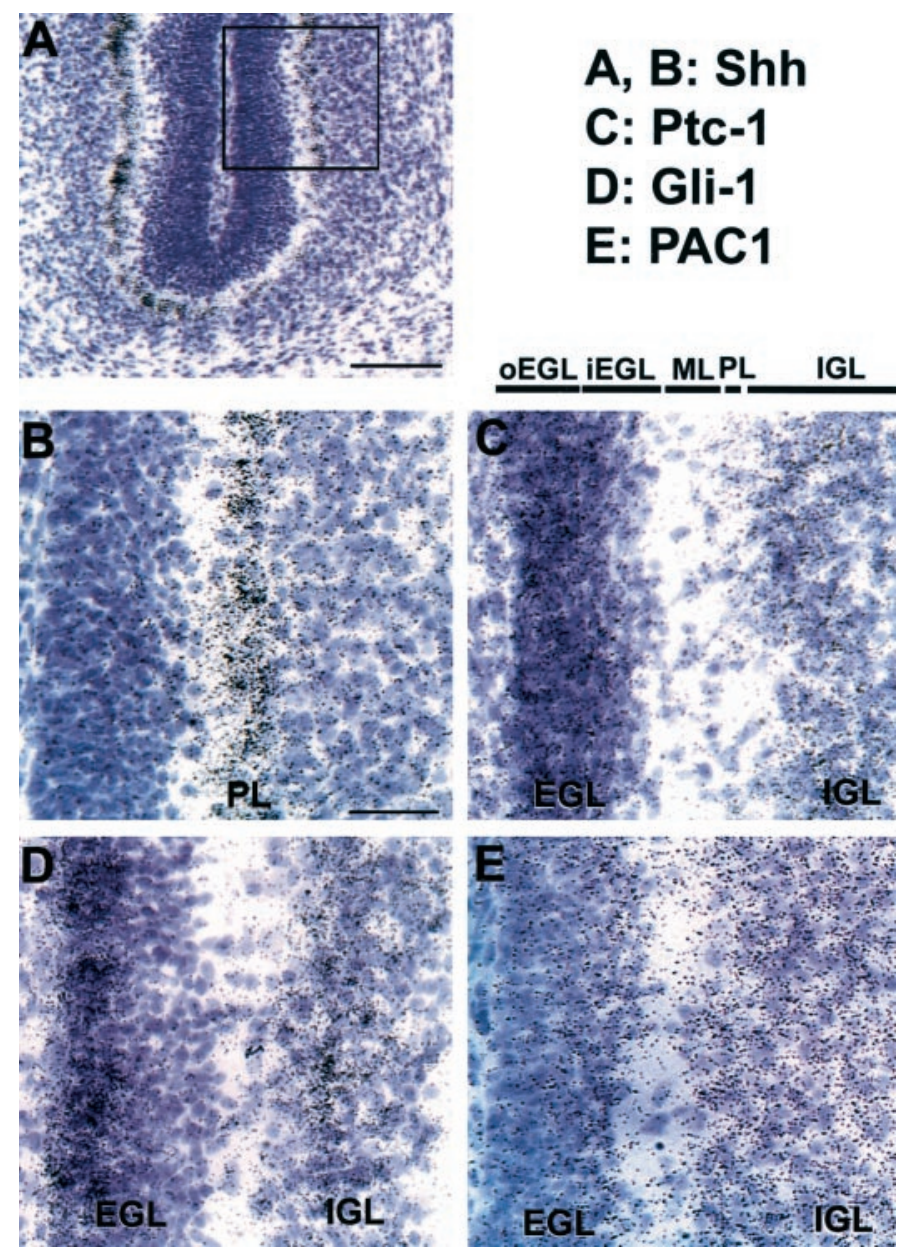

Figure 3. Localization of Shh $(A, B)$, Ptc1 $(C)$, Gli1 $(D)$, and PAC1 $(E)$ gene expression in postnatal days $5-6$ rat brain by in situ hybridization. $A$, Bright-field photomicrograph of a sagittal cerebellar section (scale bar, $100 \mu \mathrm{m})$. This section has been hybridized with the Shh probe, which localizes to the Purkinje layer. The box indicates the position of the bright-field views at higher magnification in $B-E$ (scale bar, $35 \mu \mathrm{m}) . M L$, Molecular layer; $P L$, Purkinje cell layer.

pronounced after $24 \mathrm{hr}$ of treatment, with PACAP inhibiting Shh-induced $\left[{ }^{3} \mathrm{H}\right] \mathrm{dT}$ incorporation by 50 and $85 \%$ in rat and mouse cultures, respectively (Fig. $6 C, D$ ). To determine whether the decrease was attributable to inhibition of proliferation or negative effects on cell survival, we followed the same treatment paradigm and analyzed cell number and the BrdU labeling index of mouse cells cultured for $2 \mathrm{~d}$ in DM or DM plus Shh. Mouse cells in DM (or DM plus PACAP) were never labeled with BrdU, whereas in the presence of Shh, $6.9 \pm 0.7 \%$ of the cells exhibited nuclear immunoreactivity (Fig. 8). The Shh-induced increase in BrdU labeling was associated with a 1.4-fold and fourfold increase in cell number at DIV1 and DIV2, respectively, indicating that Shh stimulates GNP proliferation. Strikingly, the addition of PACAP to Shh-treated cultures resulted in virtually no BrdU incorporation (labeling index, $0.3 \pm 0.3 \%$ ) and prevented Shhinduced proliferation. Similar BrdU labeling indices were obtained when PACAP was added as soon as $1 \mathrm{hr}$ after seeding (SHH-treated cells, $6.1 \pm 0.1 \%$; SHH plus PACAP-treated cells, $0.15 \pm 0.13 \%$; three determinations). These results indicate that PACAP can both prevent SHH mitogenic action as well as block ongoing $\mathrm{SHH}$-induced proliferation.
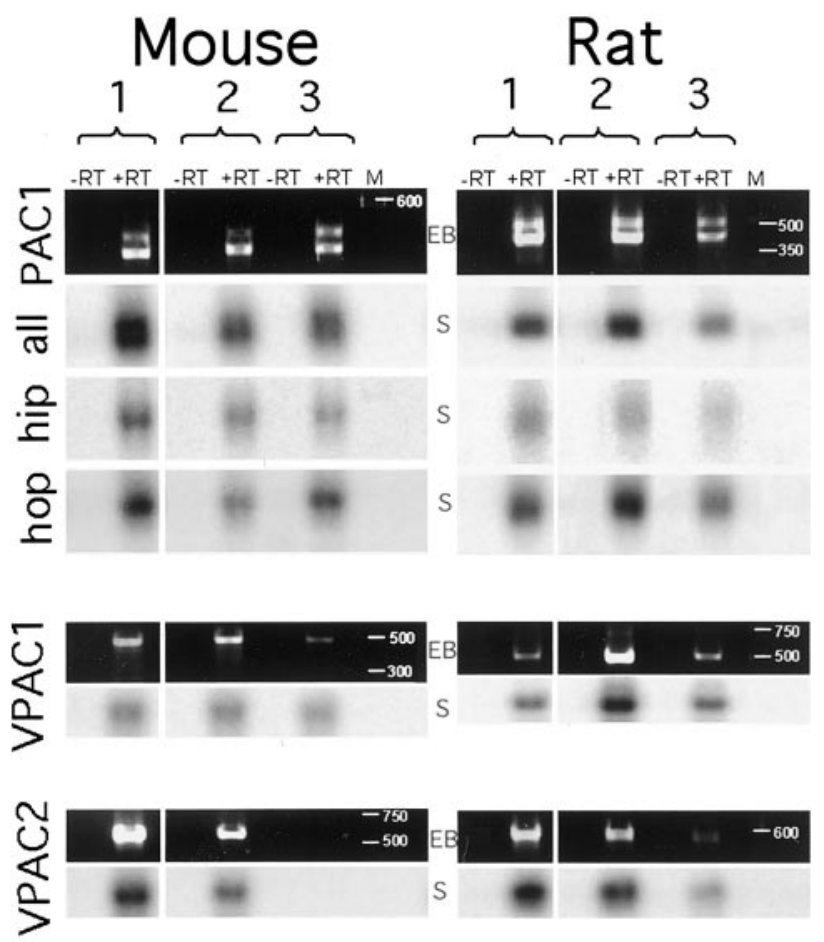

Figure 4. Expression of PAC1, VPAC1, and VPAC2 receptors by cells isolated from postnatal mouse and rat cerebellum defined by RT-PCR. Total RNA was extracted from embryonic cerebral cortex (1) or from glial/Purkinje cell (2) and granule cell (3) fractions of P6-P7 mouse and rat cerebellum and subjected to RT-PCR. Results in mouse fractions (left side) are compared with E13.5 mouse cortex. Results in rat (right side) are compared with E14.5 rat cortex. Shown for each receptor is the ethidium bromide-stained gel $(E B)$ and the Southern blot analyses directly below $(S)$ using PAC1 splice variant-, VPAC1-, and VPAC2-specific internal probes. For PAC1, both the short isoform (bottom band, $430 \mathrm{bp}$ ) and the hop isoform (top band, 460 bp) were detected, whereas the hip insert was barely detected by Southern blot. For VPAC1 and VPAC2, only one mRNA form was detected (480 and 545 bp bands, respectively). RT-PCRs performed in the absence of reverse transcriptase $(-R T)$ are shown as an indicator of absence of genomic DNA contamination. Band sizes were estimated using commercially available DNA ladder $(M)$.

In aggregate, these results indicate that PACAP differentially affects GNP mitogenesis, as a function of growth factor context and animal species. In particular, PACAP elicits modest promitogenic effects in rat cells, acting either alone or in the presence of factors in standard medium supplements, such as N2 and B27, whereas the peptide exhibits strong antimitogenic activity in Shh-stimulated mouse or rat GNP cultures.

\section{PAC1 activation mediates regulation of GNP mitogenesis}

Because PACAP binds multiple receptors, including PAC1, VPAC1, and VPAC2, we determined whether the foregoing differential ligand actions (mitogenic vs antimitogenic) depended on distinct PACAP receptors. As a first step, we examined the effects of maxadilan, a specific PAC1 agonist (Moro and Lerner, 1997), on proliferation of rat precursor mitogenesis. Maxadilan reproduced fully the differential effects of PACAP, stimulating DNA synthesis in DM and inhibiting Shh-induced mitogenesis (Fig. 9). In contrast, $10 \mathrm{~nm}$ VIP, a concentration that selectively activates VPAC1 or VPAC2, did not affect thymidine incorporation in defined medium but inhibited Shh-induced incorporation by $20 \%$ at $48 \mathrm{hr}$ (data not shown). These observations suggest 


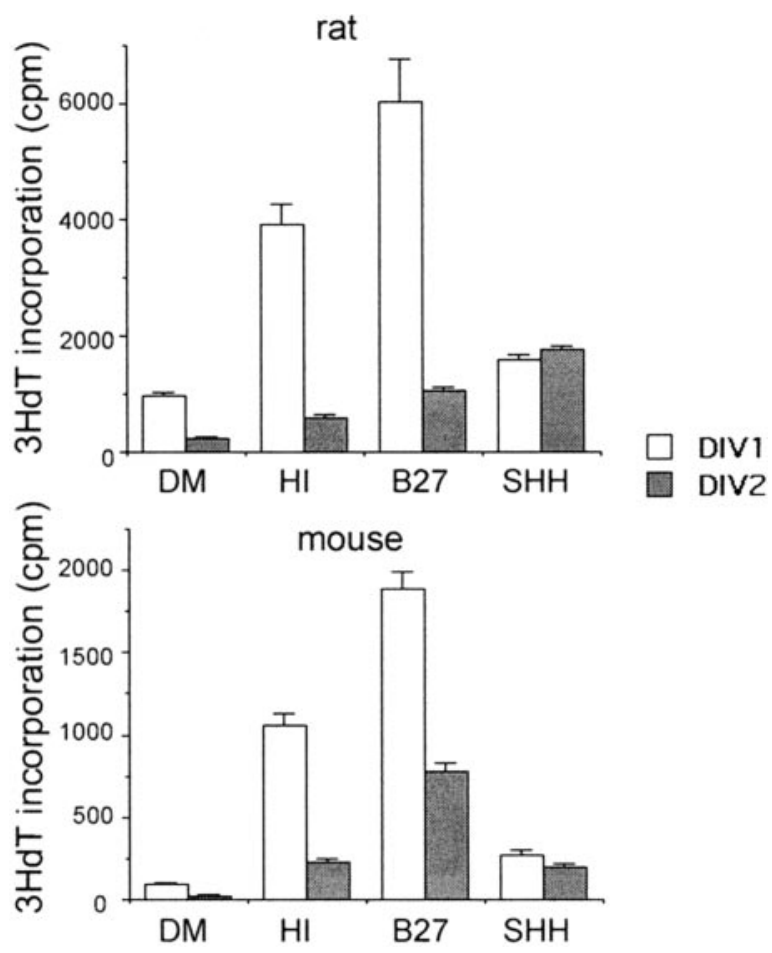

Figure 5. Effect of medium composition on rat and mouse GNP DNA synthesis. GNPs from P6 to P7 rat or mouse cerebella were cultured at $3 \times 10^{5}$ cells per well for $24 \mathrm{hr}$ (DIV1) or $48 \mathrm{hr}$ (DIV2) in DM or DM supplemented with $5 \mu \mathrm{g} / \mathrm{ml}$ insulin $(H I), 2 \%$ B27 (B27), or $3 \mu \mathrm{g} / \mathrm{ml} \mathrm{Shh}$ $(\mathrm{SHH})$. Cultures were exposed to $\left[{ }^{3} \mathrm{H}\right] \mathrm{dT}$ during the final $2 \mathrm{hr}$ of culture to assess DNA synthesis. Although HI and B27 media at DIV1 markedly stimulated $\left[{ }^{3} \mathrm{H}\right] \mathrm{dT}$ incorporation, longer exposure (DIV2) resulted in lower counts. In contrast, Shh elicited a moderate but sustained increase in GNP mitotic activity on both DIV1 and DIV2. Values are expressed as mean counts per minute per well \pm SEM (6-12 wells per group).

that, in GNPs, PAC1 mediates inhibitory or stimulatory mitotic effects depending on the presence of Shh, whereas VPAC1 and/or VPAC2 activation contributes only to inhibition. Finally, based on previous studies (Nicot and DiCicco-Bloom, 2001), differential PACAP effects may depend on the relative expression of PAC1 splice isoforms, including the short (null) and hop variants. However, quantitative RT-PCR of the PAC1 isoforms, using PAC1short/PAC1hop plasmids in different ratios as standards, did not support this hypothesis; the ratio of PAC1short to PAC1hop mRNA signals was $1 \pm 0.1$ (ratio \pm SEM, three experiments) in both control and $24 \mathrm{hr}$ Shh-treated rat GNPs.

\section{Adenylate cyclase pathway activation differentially inhibits GNP mitogenesis}

Because PACAP receptors classically couple to adenylate cyclase (Arimura, 1998) and the adenylate cyclase activator forskolin can suppress Shh-induced mitosis in mouse retinal (Jensen and Wallace, 1997) and cerebellar (Wechsler-Reya and Scott, 1999) precursors in culture, we defined the effects of forskolin in the different media. Forskolin treatment elicited significant decreases in $\left[{ }^{3} \mathrm{H}\right] \mathrm{dT}$ incorporation at both 6 and $24 \mathrm{hr}$ in media supplemented with high insulin, B27, or Shh in rat and mouse cell cultures, although the drug was without effect at $6 \mathrm{hr}$ in DM, which lacks mitogens (Table 1). The drug was indeed active, because a $15 \mathrm{~min}$ forskolin exposure induced phosphorylation of nuclear cAMP response element-binding protein (CREB) (control, $0.1 \pm 0.1 \%$; forskolin-treated, $92 \pm 2 \%$; percentage of cells

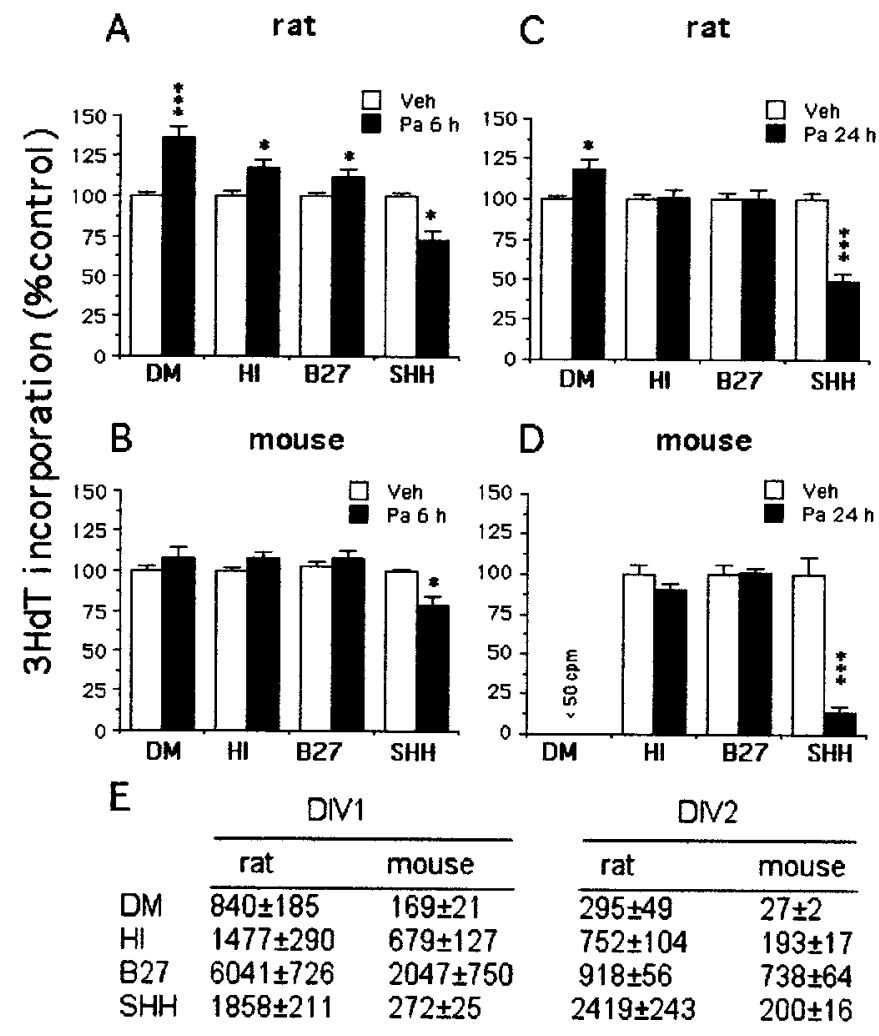

Figure 6. Effects of PACAP treatment on DNA synthesis. Purified P6-P7 cerebellar GNPs were plated at 250,000 cells per well in various media. The next day (DIV1), cells were treated with $10 \mathrm{~nm}$ PACAP $(\mathrm{Pa})$ or vehicle $(V e h)$ for $6 \mathrm{hr}(A, B)$ or $24 \mathrm{hr}(\mathrm{DIV} 2)(C, D)$. Cultures were pulsed with $\left[{ }^{3} \mathrm{H}\right] \mathrm{dT}$ for the final $2 \mathrm{hr}$ and processed for $\left[{ }^{3} \mathrm{H}\right] \mathrm{dT}$ incorporation. $A$, PACAP treatment stimulated rat GNP mitosis in DM (no mitogen), DM plus insulin $(5 \mu \mathrm{g} / \mathrm{ml})(H I)$, and B27-supplemented medium (B27), whereas the peptide slightly reduced Shh-induced $\left[{ }^{3} \mathrm{H}\right] \mathrm{dT}$ incorporation. $B$, In mouse cultures, PACAP was not sufficient to stimulate GNP mitosis but reduced Shh-induced $\left[{ }^{3} \mathrm{H}\right] \mathrm{dT}$ incorporation by $20 \%$. $C$, PACAP treatment slightly stimulated rat GNP mitosis in DM, whereas the peptide reduced Shh-mediated proliferation by $50 \%$. $D$, In mouse cultures, PACAP was not sufficient to maintain GNP proliferation in DM ( $<50 \mathrm{cpm}$ in both controls and treated groups). However, in the presence of Shh, PACAP inhibited mitosis by $85 \%$. Data are expressed as a percentage of vehicle control for each medium (9-12 wells per group). $* p<0.05$; $* * * p<0.001$. $E$, counts per minute values from control cultures (vehicle treated) are indicated as mean $\pm \operatorname{SEM}(n=3-4$ independent experiments for each medium).

exhibiting nuclear phospho-CREB immunoreactivity) (data not shown). Strikingly, forskolin induced far greater inhibition of DNA synthesis in mouse than in rat cultures, leading to an $85 \%$ reduction in Shh-induced mitosis at $24 \mathrm{hr}$. Thus, mouse GNPs are apparently more sensitive to cAMP stimulation than rat neuroblasts, potentially accounting for the more pronounced PACAP inhibitory effects observed. These observations are consistent with previous reports of greater forskolin-induced inhibition of Shh mitogenesis in mice (Jensen and Wallace, 1997; WechslerReya and Scott, 1999; Kenney and Rowitch, 2000) than in rats (Pons et al., 2001). Although it is unclear whether response differences in the foregoing cited studies depended on species or culture media, our comparative studies with forskolin (and PACAP) using identical media indicate that mouse GNPs are indeed more sensitive to CAMP-mediated inhibition than rat precursors under several culture conditions. 

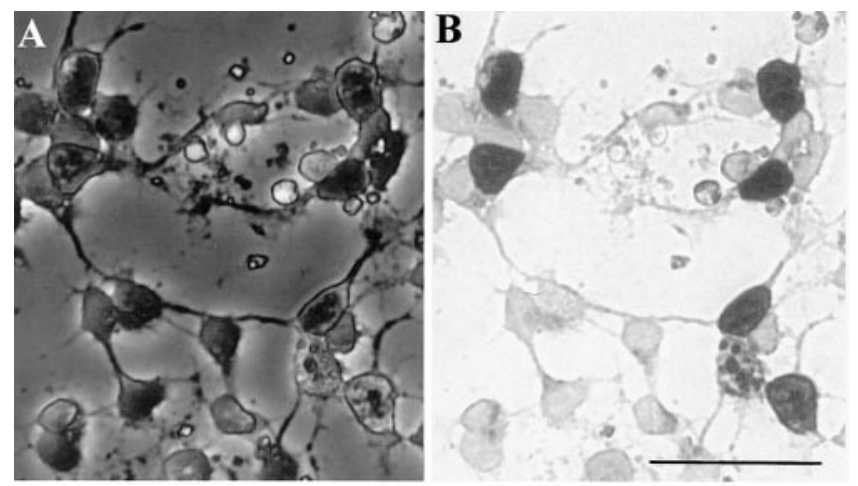

C

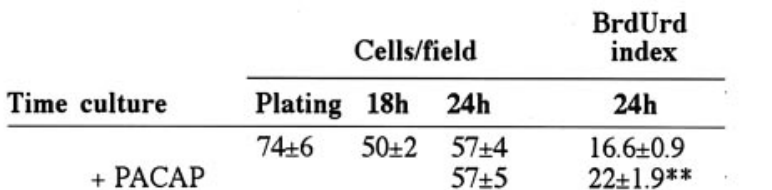

Figure 7. PACAP stimulates BrdU labeling. P7 rat cells were cultured for $24 \mathrm{hr}$ in DM and exposed to $10 \mathrm{~nm}$ PACAP for the final $6 \mathrm{hr}$. After a pulse of $10 \mu \mathrm{M} \mathrm{BrdU}$ for the final $4 \mathrm{hr}$, cells were processed for BrdU immunocytochemistry. $A, B$, Cells are visualized by phase $(A)$ or brightfield $(B)$ microscopy after immunocytochemical staining. Cells were counted in five random fields per dish at 3,18 , and $24 \mathrm{hr}$ of culture (5 dishes per group), and data are presented in a table $(C)$. PACAP treatment did not affect cell number but increased BrdU (BrdUrd) labeling index, indicating that PACAP treatment for $6 \mathrm{hr}$ increased S phase entry independent of possible survival effects. Cell number per field in corresponding cultures and BrdU index are expressed as mean \pm SEM. $* * p<$ 0.01 , PACAP effect. Scale bar, $35 \mu \mathrm{m}$.

\section{Opposing effects of the adenylate cyclase and $\mathrm{PLC} /$ protein kinase $\mathbf{C}$ pathways}

Previous studies indicate that PACAP stimulates adenylate cyclase as well as phospholipase $\mathrm{C}$ in cerebellar cultures (Basille et al., 1995). Moreover, in cerebral cortical precursor cultures, activation of these two pathways has opposite effects on proliferation (Nicot and DiCicco-Bloom, 2001). Thus, we compared the effect of $6 \mathrm{hr}$ of treatment with forskolin and the protein kinase C (PKC) activator PMA on the mitotic activity of mouse GNPs. In the presence of high insulin, forskolin treatment elicited a 50\% decrease in incorporation, whereas PMA stimulated DNA synthesis by $40 \%$ (Fig. 10). These observations support the antagonistic actions of these two pathways in cerebellar neuroblasts. Consequently, the relative balance between adenylate cyclase and phospholipase $\mathrm{C}$ pathways may explain the lack of effect of PACAP on mitogenesis observed in mouse cells, in contrast to rat cells, which are less sensitive to cAMP-induced inhibition (Table 1). These data may also account for the promitogenic effects of PAC1 receptor activation, which stimulates PLC, whereas activation of VPAC1/2 receptors (which couple to adenylate cyclase but not PLC) only leads to antimitogenic effects.

\section{DISCUSSION}

Our observations indicate that cerebellar GNPs express functional G-protein-coupled receptors of the PACAP/VIP system and primarily PAC1, which colocalizes with the Shh receptor, Ptc1, and its target gene Gli1 in the developing EGL. Moreover, as PAC1 initiates cAMP signaling in mitotic neuroblasts, PAC1 agonists, including PACAP and maxadilan, elicit robust inhibition of Shh-induced GNP proliferation in both rat and mouse precursors, suggesting important interactions during development. Finally, because PACAP can stimulate GNP mitosis in the absence
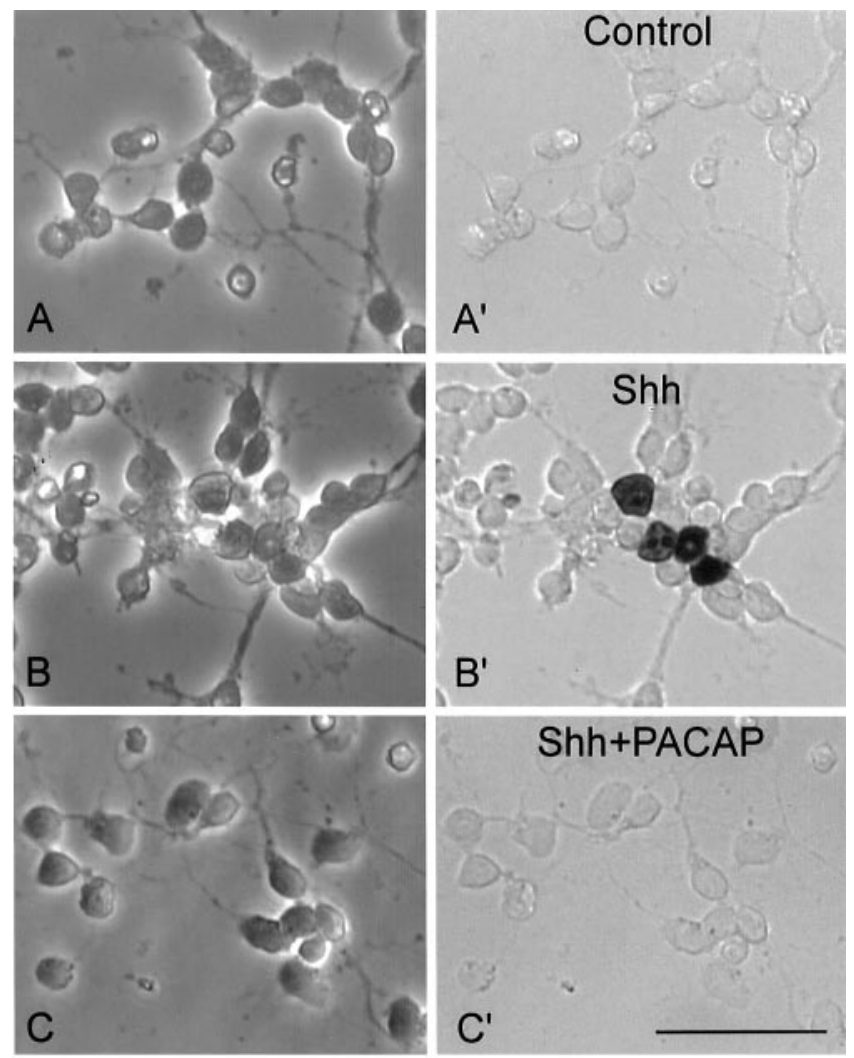

D

Cell number/field

\begin{tabular}{|c|c|c|}
\hline Plating & $24 \mathrm{~h}$ & $48 \mathrm{~h}$ \\
\hline Control $\quad 100 \pm 7$ & $109 \pm 6$ & $\begin{array}{l}85 \pm 5 \\
76+11\end{array}$ \\
\hline $\begin{array}{l}\text { Shh } \\
\text { Shh + PACAP }\end{array}$ & $157 \pm 3$ & $\begin{array}{l}344 \pm 3 \\
103 \pm 12\end{array}$ \\
\hline
\end{tabular}

Figure 8. PACAP inhibits BrdU labeling in Shh-treated GNPs. Phasecontrast $(A-C)$ and bright-field $\left(A^{\prime}-C^{\prime}\right)$ photographs of cells after BrdU immunocytochemistry. P7 mouse cells were cultured for $2 \mathrm{~d}$ in defined medium (Control) $\left(A, A^{\prime}\right)$ or defined medium with $3 \mu \mathrm{g} / \mathrm{ml} \mathrm{Shh}\left(B, B^{\prime}\right) . C$, $\mathrm{C}^{\prime}$, Shh-treated cells exposed to $10 \mathrm{~nm}$ PACAP for the last $24 \mathrm{hr}$. Cultures were pulsed with $10 \mu \mathrm{M}$ BrdU for the final $4 \mathrm{hr}$ and processed for BrdU immunocytochemistry. $D$, Cell number per field in corresponding cell cultures expressed as mean \pm SEM. Scale bar, $35 \mu \mathrm{m}$.

of Shh, these studies demonstrate a critical role for G-proteincoupled receptors as sensors of environmental levels of regulatory signals, potentially providing mechanisms for coordinating brain neurogenesis.

\section{PACAP receptors and regulation of neural development}

The PACAP/VIP systems regulate diverse aspects of neural development in the embryo, as indicated by studies of expression and experimental manipulation in culture. PACAP and its receptors are widely expressed in neurons of the embryonic and neonatal brain, exhibiting region-specific and developmentally regulated patterns (Nielsen et al., 1998; Waschek et al., 1998; Basille et al., 2000; Jaworski and Proctor, 2000). Furthermore, PACAP agonist and antagonist studies demonstrate peptide regulation of neuroblast proliferation and differentiation in both the peripheral nervous system and CNS (Lu and DiCicco-Bloom, 1997; Waschek et al., 1998; DiCicco-Bloom et al., 2000; Suh et al., 2001). In 


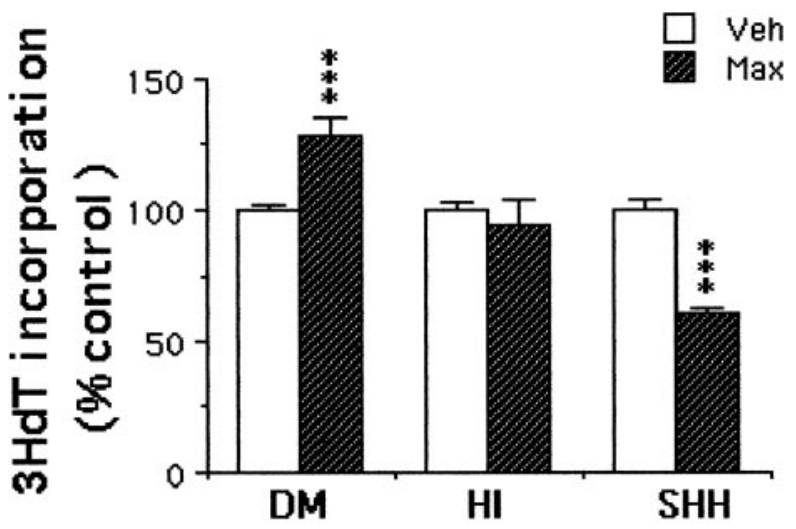

Figure 9. Effect of the PAC1-selective agonist maxadilan on GNP DNA synthesis. Rat (P7) cells were incubated in DM, DM plus insulin (5 $\mu \mathrm{g} / \mathrm{ml})(H I)$, or Shh $(3 \mu \mathrm{g} / \mathrm{ml})(S H H)$ for $16 \mathrm{hr}$ and treated for an additional $24 \mathrm{hr}$ with $10 \mathrm{~nm}$ maxadilan (Max). Cultures were pulsed with $\left[{ }^{3} \mathrm{H}\right] \mathrm{dT}$ for the final $2 \mathrm{hr}$ and processed for $\left[{ }^{3} \mathrm{H}\right] \mathrm{dT}$ incorporation. Data are expressed as a percentage of control (Veh, vehicle). Data are derived from two to three experiments $(8-12$ wells per group). $* * * p<0.001$.

Table 1. Effect of forskolin treatment on DNA synthesis

\begin{tabular}{lcclll} 
& \multicolumn{3}{l}{ Rat } & & Mouse \\
\cline { 2 - 3 } \cline { 5 - 6 } & $6 \mathrm{hr}$ & $24 \mathrm{hr}$ & & $6 \mathrm{hr}$ & $24 \mathrm{hr}$ \\
\hline DM & $8 \pm 3$ & $-19 \pm 1.1^{*}$ & & N.D. & N.D. \\
HI & $-25 \pm 3^{*}$ & $-30 \pm 1.7^{*}$ & & $-56 \pm 2.5^{*}$ & $-83 \pm 14^{*}$ \\
B27 & N.D. & $-30 \pm 2.1^{*}$ & & $-54 \pm 4.6^{*}$ & $-73 \pm 8^{*}$ \\
SHH & N.D. & $-61 \pm 7.8^{*}$ & & N.D. & $-86 \pm 12^{*}$
\end{tabular}

Forskolin $(30 \mu \mathrm{M})$ was applied for 6 or $24 \mathrm{hr}$ to assess effects of adenylate cyclase activation on $\left[{ }^{3} \mathrm{H}\right] \mathrm{dT}$ incorporation in rat and mouse cells. Data are expressed as a percentage decrease compared with vehicle. N.D., Not determined; HI, defined medium with insulin $(5 \mu \mathrm{g} / \mathrm{ml})$; B27, defined medium with B27 supplements; $\mathrm{SHH}$, defined medium with sonic hedgehog $(3 \mu \mathrm{g} / \mathrm{ml})$. Note that forskolin was more active in mouse cultures than in rat cultures. Data are derived from two experiments $(6-8$ wells per group). ${ }^{*} p<0.05$ versus vehicle.

addition to neurogenesis, the PACAP/VIP systems are important in neuroprotection, acting directly or via glial release of neurotrophic signals, as well as in glial function (for review, see Lindholm et al., 1998; Waschek, 2002).

Our current studies provide new evidence for a role in cerebellar neurogenesis. During postnatal development, PACAP is expressed by Purkinje cells (Skoglosa et al., 1999), and PACAPimmunoreactive fibers approach GNPs in the EGL (Nielsen et al., 1998). We now show that PAC1 is expressed by GNPs in the developing EGL at its inception prenatally in the rhombic lip, at $\mathrm{P} 0-\mathrm{P} 1$ when cell proliferation in the EGL commences, and at $\mathrm{P} 5-\mathrm{P} 7$, the peak of precursor pool proliferation and granule neuron generation. These studies are consistent with recent transcript expression and ligand-binding studies (Basille et al., 2000; Jaworski and Proctor, 2000), providing a molecular basis for regulatory functions. Previous work indicated that PACAP promotes survival of cerebellar granule cells in culture (Gonzalez et al., 1997; Villalba et al., 1997), an effect that may account for PACAP-induced growth of the IGL in vivo (Vaudry et al., 1999). However, our present data suggest additional roles of PACAP and a novel interaction with Shh in regulating cerebellar GNP proliferation.

\section{PAC1 isoforms in developing cerebellum}

Because PAC1 receptor isoforms may determine the stimulatory or inhibitory action of the peptide, characterization of isoform

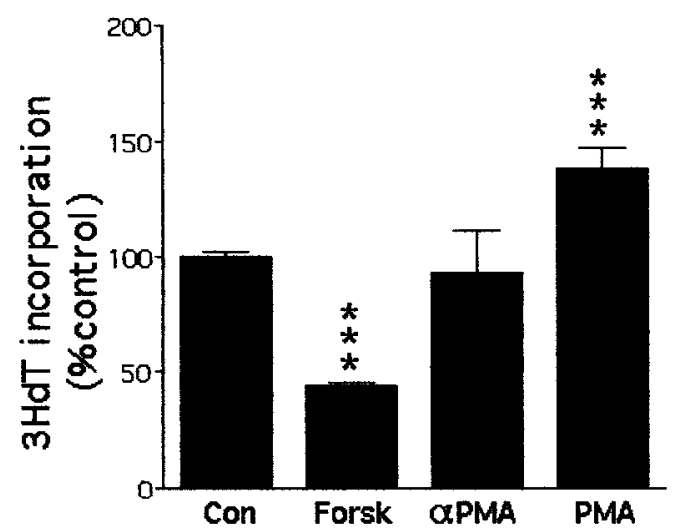

Figure 10. Opposing effects of adenylate cyclase and phospholipase C pathways on DNA synthesis. P6-P7 mouse cells were cultured in the presence of high insulin for $16 \mathrm{hr}$ and treated for $6 \mathrm{hr}$ with $30 \mu \mathrm{M}$ forskolin (Forsk), vehicle (Con, control; $0.05 \%$ DMSO, $0.05 \%$ ethanol), phorbol ester PMA $(0.2 \mu \mathrm{M})$, or inactive enantiomer $\alpha$ PMA. Cultures were pulsed with $\left[{ }^{3} \mathrm{H}\right] \mathrm{dT}$ for the final $2 \mathrm{hr}$ and processed for $\left[{ }^{3} \mathrm{H}\right] \mathrm{dT}$ incorporation. Data are expressed as a percentage of vehicle (9 wells per group). $* * * p<$ 0.001 versus control

expression may suggest the role of PACAP in postnatal neurogenesis. Previous RT-PCR expression studies of PAC1 variants using whole rat cerebellar extracts indicated a preponderance of the hop variant at P4 and of the short isoform after P8 (D'Agata et al., 1996; Jaworski, 2000). Both short and hop isoforms were identified in isolated granule neurons in vitro (Cavallaro et al., 1996; Villalba et al., 1997), whereas the short form predominated in cultured cerebellar glia (Campard et al., 1997) and specifically astrocytes (Jaworski, 2000). Our RT-PCR studies of freshly purified GNPs indicate that both isoforms are expressed with no change in relative abundance from P5 to P10. Thus, we speculate that the ontogenetic switch in receptor isoform reported previously and detected in whole cerebellar extracts reflects expression changes in other neuronal or glial populations and is not responsible for the complex proliferative regulation we observe.

\section{Integration of antimitogenic and promitogenic signals for granule neuron production in the cerebellum}

Locally produced or peripherally circulating growth factors, such as fibroblast growth factor (FGF), epidermal growth factor (EGF), and IGF-1, have been shown to promote granule cell proliferation or survival (Gao et al., 1991; Tao et al., 1996; Ye et al., 1996; Lin and Bulleit, 1997; Traiffort et al., 1999; Cheng et al., 2001). Secreted by Purkinje cells, Shh is also an efficacious mitogen for GNPs. The fact that GNPs exit the cell cycle in the middle of the EGL, just as they approach a putatively primary source of Shh (Purkinje neurons), suggests that antimitogenic signals must overcome the stimulatory effects of an increasing Shh concentration. How these cells establish and maintain their differentiation program in this Shh-rich mitogenic environment is not well understood. Our data suggest that PACAP may provide an antimitogenic signal. This inhibitory action is specific to Shh, because it was not observed in the presence of other mitogens present in N2- or B27-containing media. Indeed, PACAP is a significant promitogenic factor in rat granule cultures in the absence of Shh.

Thus, the effects of PACAP on GNP proliferation depend on the mitogenic environment. One mediating mechanism could be that environmental cues modulate the relative expression of PAC1 isoforms. In previous work, we demonstrated a link be- 
Figure 11. Model of PACAP regulation of granule precursor proliferation. Granule precursors are depicted in the outer EGL $(A)$ and inner EGL $(B)$, with the complex of soluble, extracellular signals and their receptors, including Shh/Ptc-Smo, SDF-1/CXCR4, and PACAP/PAC1 (adapted from Klein et al., 2001). $A$, Near the pia matter during the first postnatal week, granule cell proliferation is high. Prominent expression of SDF-1/CXCR4 blocks adenylate cyclase activity and cAMP via $G_{\alpha i}$ coupling, thereby promoting Shh-induced proliferation. PAC1 activation may moderately stimulate mitogenesis via the $\mathrm{G}_{\mathrm{q}}$ /phospholipase $\mathrm{C} /$ protein kinase $\mathrm{C}$ pathway. $B$, In the inner EGL as development progresses, SDF-1 and CXCR4 levels decrease. In turn, the proliferative action of Shh is now blocked by PACAP via $\mathrm{G}_{\mathrm{s}}$ activation of adenylate cyclase through PAC1 (and possibly VPAC1) receptors. PACAP may be derived from nerve fibers emerging from the Purkinje layer or brainstem nuclei. $M L$, Molecular layer; $P L$, Purkinje cell layer; $P M$, pia matter.

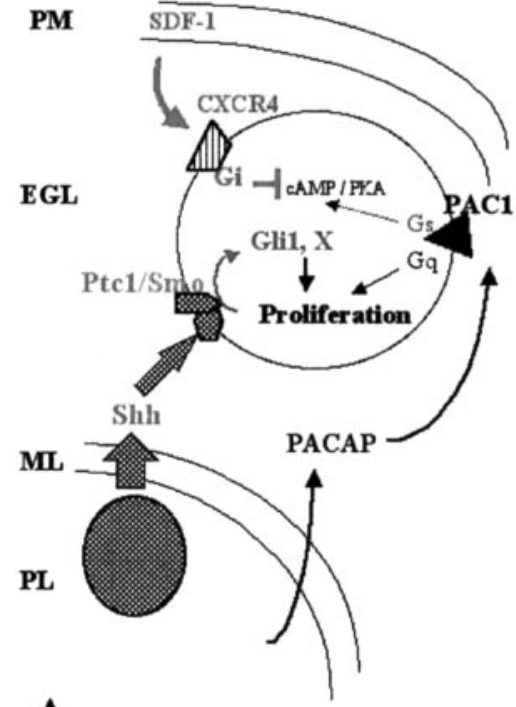

A

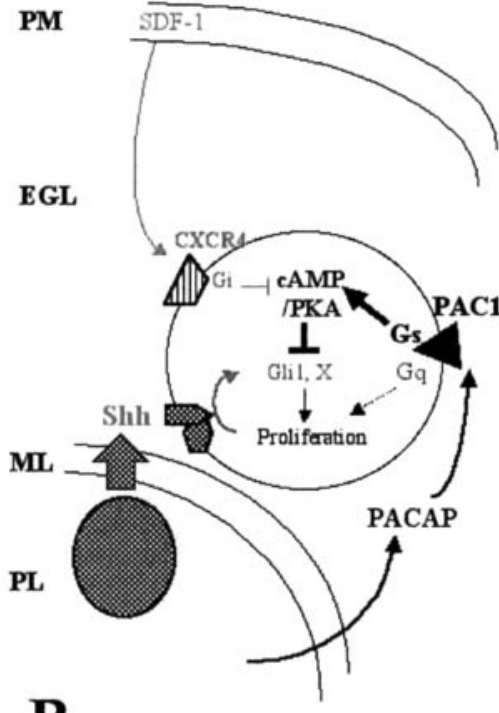

B tween PAC1 receptor isoform (short vs hop) expression and activation of intracellular signaling pathways and proliferation (Lu et al., 1998; Nicot and DiCicco-Bloom, 2001). By analogy, a switch in the ratio of PAC1 splice isoforms in GNPs may account for Shh-dependent effects on proliferation. However, we found that GNPs cultured with or without Shh express both isoforms equally. Rather, our data favor an alternative mechanism. The specific pathways activated by PACAP might instead depend on environmental context. When dividing GNPs migrate through the EGL toward the IGL, they are exposed to a Shh-rich milieu provided by Purkinje neurons. Because Shh can act by antagonizing PKA-dependent processes, the cells might be particularly sensitive to factors stimulating $\mathrm{CAMP} / \mathrm{PKA}$ at this stage. Indeed, our data suggest that PAC1 activation may be sufficient at the EGL/ molecular and Purkinje layer interface to counteract the mitogenic effects of Shh, potentially serving to maintain the quiescence of granule cells in the IGL (Cunningham and Roussel, 2001). However, in the EGL near the pia mater, adenylate cyclase activity may be strongly inhibited by factors such as the chemokine stromal-derived factor- $1 \alpha$ (SDF-1), which is highly expressed by the pia mater during the first postnatal days and acts on EGL precursors through the Gi-coupled serpentine receptor CXCR4 (Klein et al., 2001). Thus, in this location, PACAP may exert only its promitogenic activity through PLC and/or other pathway activation (Fig. 11). Moreover, other mechanisms involving cellcell contact may also participate in regulation of GNP proliferation (Gao et al., 1991). Finally, the outer versus the innermost portions of the EGL and the Purkinje cell layer exhibit striking differences in the composition of extracellular matrix glycoproteins and their integrin receptors, which may provide specific modulation of peptide mitogenic or antimitogenic signaling (Pons et al., 2001).

\section{Potential mechanisms of Shh-PACAP interactions}

Because PACAP markedly inhibits Shh mitogen action (but not proliferation induced by high insulin or B27), the peptide likely acts selectively on the Hedgehog pathway, which is highly dependent on cAMP signaling. Such signaling interaction may include actions on Ptc1, Smo, and Gli1 signaling, as well as unrelated pathways. Although the ras-extracellular signal-regulated kinase pathway regulates cell proliferation in a variety of cell types and may be governed by cAMP (Grewal et al., 1999), it is not involved in the proliferative effects of Shh in GNPs (Kenney and Rowitch, 2000). Thus, this pathway is an unlikely target for the antimitogenic effects of PACAP, although it plays a postmitotic role in PACAP-mediated survival of cerebellar granule neurons (Gonzalez et al., 1997; Villalba et al., 1997).

However, Shh rapidly induces target genes such as Gli1 (Ruiz i Altaba, 1999), a transcriptional effector in skin tumors (Toftgard, 2000). As the earliest target, Gli transcription factors are likely candidates for regulating GNP proliferation, although studies remain to be performed. For example, Gli3 is an activator of the Shh target gene Gli1. However, in the presence of PKA stimulation, Gli3 is converted into a transcriptional repressor (Dai et al., 1999), suggesting a possible locus of PACAP action. In contrast, Gli transcription factors share with the cAMPresponsive transcription factor $\mathrm{CREB}$ and the transcriptional adapters CREB binding protein and p300 (Lundblad et al., 1995; Akimaru et al., 1997). PACAP rapidly elicits nuclear phosphoCREB, and CREB overexpression is sufficient to induce granule cell differentiation in the presence of Shh (Pons et al., 2001). Thus, phospho-CREB signaling may overcome Shh mitogenic action by directly interacting or competing with Gli transcriptional complexes for the adapter proteins. This scenario may occur in vivo, because phospho-CREB is observed primarily in granule cells at the level of the Purkinje cell layer, where they are engaged in differentiation (Pons et al., 2001). Indeed, the high levels of PAC1 expression in the iEGL as well as the in Purkinje layer and IGL are entirely consistent with PACAP serving as a regulator of CREB activation and cell differentiation.

Finally, PACAP may affect pathways regulated by Shh that are independent of the Ptc-Smo receptor and Gli transcription factors, including those involved in cell migration (Testaz et al., 2001), induction of hairy enhancer of split-1 transcription factor (Solecki et al., 2001), and cell-cycle control, such as cyclin D1 (Kenney and Rowitch, 2000) and cyclin B1 (Barnes et al., 2001). Although PACAP is known to rapidly elicit increased levels of cyclin-dependent kinase inhibitor p57 to block cell-cycle progression of cerebral cortical precursors (Carey et al., 2002), the peptide inhibits all cortical mitogens, including FGF, IGF, and EGF (Lu and DiCicco-Bloom, 1997). In contrast, our studies in 
prenatal hindbrain (Lelievre et al., 2002) and postnatal cerebellum indicate selective actions of PACAP, depending on mitogenic environment. Additional studies are required to determine the mechanism(s) of mitogen-selective antimitotic effects of PACAP.

More generally, these studies identify a new function of G-protein-coupled receptors as potential sensors of environmental cues during cerebellar histogenesis. Moreover, the potent antimitogenic effects of PACAP in the context of Shh-mediated proliferation suggest that the PAC1 receptor may be a useful therapeutic target in childhood medulloblastoma, a granule cell malignancy driven by abnormal Shh signaling (Dong et al., 2000; Zurawel et al., 2000; Pomeroy et al., 2002).

\section{REFERENCES}

Akimaru H, Chen Y, Dai P, Hou DX, Nonaka M, Smolik SM, Armstrong S, Goodman RH, Ishii S (1997) Drosophila CBP is a co-activator of cubitus interruptus in hedgehog signalling. Nature 386:735-738.

Alder J, Cho NK, Hatten ME (1996) Embryonic precursor cells from the rhombic lip are specified to a cerebellar granule neuron identity. Neuron 17:389-399.

Altman J, Bayer SA (1996) Development of the cerebellar system in relation to its evolution, structure and functions. New York: CRC.

Arimura A (1998) Perspectives on pituitary adenylate cyclase activating polypeptide (PACAP) in the neuroendocrine, endocrine, and nervous systems. Jpn J Physiol 48:301-331.

Barnes EA, Kong M, Ollendorff V, Donoghue DJ (2001) Patched1 interacts with cyclin B1 to regulate cell cycle progression. EMBO J 20:2214-2223.

Basille M, Gonzalez BJ, Desrues L, Demas M, Fournier A, Vaudry H (1995) Pituitary adenylate cyclase-activating polypeptide (PACAP) stimulates adenylyl cyclase and phospholipase $\mathrm{C}$ activity in rat cerebellar neuroblasts. J Neurochem 65:1318-1324.

Basille M, Vaudry D, Coulouarn Y, Jegou S, Lihrmann I, Fournier A, Vaudry H, Gonzalez B (2000) Comparative distribution of pituitary adenylate cyclase-activating polypeptide (PACAP) binding sites and PACAP receptor mRNAs in the rat brain during development. J Comp Neurol 425:495-509.

Brewer G (1995) Serum-free B27/neurobasal medium supports differentiated growth of neurons from the striatum, substantia nigra, septum, cerebral cortex, cerebellum, and dentate gyrus. J Neurosci Res 42:674-683.

Campard PK, Crochemore C, Rene F, Monnier D, Koch B, Loeffler JP (1997) PACAP type I receptor activation promotes cerebellar neuron survival through the cAMP/PKA signaling pathway. DNA Cell Biol 16:323-333.

Carey RG, Li B, DiCicco-Bloom E (2002) Pituitary adenylate cyclase activating polypeptide anti-mitogenic signaling in cerebral cortical progenitors is regulated by $\mathrm{p} 57^{\mathrm{Kip} 2}$-dependent CDK2 activity. J Neurosci 22:1583-1591.

Cavallaro S, Copani A, D’Agata V, Musco S, Petralia S, Ventra C, Stivala F, Travali S, Canonico PL (1996) Pituitary adenylate cyclase activating polypeptide prevents apoptosis in cultured cerebellar granule neurons. Mol Pharmacol 50:60-66.

Chatterjee TK, Sharma RV, Fisher RA (1996) Molecular cloning of a novel variant of the pituitary adenylate cyclase-activating polypeptide (PACAP) receptor that stimulates calcium influx by activation of L-type calcium channels. J Biol Chem 271:32226-32232.

Cheng Y, Tao Y, Black IB, DiCicco-Bloom E (2001) A single peripheral injection of basic fibroblast growth factor (bFGF) stimulates granule cell production and increases cerebellar growth in newborn rats. J Neurobiol 46:220-229.

Cui H, Bulleit RF (1998) Potassium chloride inhibits proliferation of cerebellar granule neuron progenitors. Brain Res Dev Brain Res 106:129-135.

Cunningham JJ, Roussel MF (2001) Cyclin-dependent kinase inhibitors in the development of the central nervous system. Cell Growth Differ 12:387-396.

D'Agata V, Cavallaro S, Stivala F, Canonico PL (1996) Tissue-specific and developmental expression of pituitary adenylate cyclase-activating polypeptide (PACAP) receptors in rat brain. Eur J Neurosci 8:310-318.

Dahmane N, Ruiz-i-Altaba A (1999) Sonic hedgehog regulates the growth and patterning of the cerebellum. Development 126:3089-3100.

Dai P, Akimaru H, Tanaka Y, Maekawa T, Nakafuku M, Ishii S (1999) Sonic Hedgehog-induced activation of the Gli1 promoter is mediated by GLI3. J Biol Chem 274:8143-8152.

DiCicco-Bloom E, Cohen RE, Black I (1989) Insulin growth factors regulate mitosis and survival in cultured cerebellar granule cells and precursors. Soc Neurosci Abstr 15:328.

DiCicco-Bloom E, Deutsch PJ, Maltzman J, Zhang J, Pintar JE, Zheng J, Friedman WF, Zhou X, Zaremba T (2000) Autocrine expression and ontogenetic functions of the PACAP ligand/receptor system during sympathetic development. Dev Biol 219:197-213.

D’Mello SR, Galli C, Ciotti T, Calissano P (1993) Induction of apoptosis in cerebellar granule neurons by low potassium: inhibition of death by insulin-like growth factor I and cAMP. Proc Natl Acad Sci USA 90:10989-10993.

Dong J, Gailani MR, Pomeroy SL, Reardon D, Bale AE (2000) Identification of PATCHED mutations in medulloblastomas by direct sequencing. Hum Mutat 16:89-90.

Echelard Y, Epstein DJ, St-Jacques B, Shen L, Mohler J, McMahon JA, McMahon AP (1993) Sonic hedgehog, a member of a family of putative signaling molecules, is implicated in the regulation of CNS polarity. Cell 75:1417-1430.

Fan CM, Porter JA, Chiang C, Chang DT, Beachy PA, Tessier-Lavigne M (1995) Long-range sclerotome induction by sonic hedgehog: direct role of the amino-terminal cleavage product and modulation by the cyclic AMP signaling pathway. Cell 81:457-465.

Gao WO, Heintz N, Hatten ME (1991) Cerebellar granule cell neurogenesis is regulated by cell-cell interactions in vitro. Neuron 6:705-715.

Gonzalez BJ, Basille M, Vaudry D, Fournier A, Vaudry H (1997) Pituitary adenylate cyclase-activating polypeptide promotes cell survival and neurite outgrowth in rat cerebellar neuroblasts. Neuroscience 78:419-430.

Grewal SS, York RD, Stork PJ (1999) Extracellular-signal-regulated kinase signalling in neurons. Curr Opin Neurobiol 9:544-553.

Hammerschmidt M, Bitgood MJ, McMahon AP (1996) Protein kinase A is a common negative regulator of Hedgehog signaling in the vertebrate embryo. Genes Dev 10:647-658.

Harmar AJ, Arimura A, Gozes I, Journot L, Laburthe M, Pisegna JR, Rawlings SR, Robberecht P, Said SI, Sreedharan SP, Wank SA, Waschek JA (1998) International Union of Pharmacology. XVIII. Nomenclature of receptors for vasoactive intestinal peptide and pituitary adenylate cyclase-activating polypeptide. Pharmacol Rev 50:265-270.

Hatten ME (1985) Neuronal regulation of astroglial morphology and proliferation in vitro. J Cell Biol 100:384-396.

Jaworski DM (2000) Expression of pituitary adenylate cyclase-activating polypeptide (PACAP) and the PACAP-selective receptor in cultured rat astrocytes, human brain tumors, and in response to acute intracranial injury. Cell Tissue Res 300:219-230.

Jaworski DM, Proctor MD (2000) Developmental regulation of pituitary adenylate cyclase-activating polypeptide and PAC(1) receptor mRNA expression in the rat central nervous system. Brain Res Dev Brain Res 120:27-39.

Jensen AM, Wallace VA (1997) Expression of Sonic hedgehog and its putative role as a precursor cell mitogen in the developing mouse retina. Development 124:363-371.

Kenney AM, Rowitch DH (2000) Sonic hedgehog promotes G(1) cyclin expression and sustained cell cycle progression in mammalian neuronal precursors. Mol Cell Biol 20:9055-9067.

Kingsbury AE, Gallo V, Woodhams PL, Balazs R (1985) Survival, morphology and adhesion properties of cerebellar interneurones cultured in chemically defined and serum-supplemented medium. Brain Res 349:17-25.

Klein RS, Rubin JB, Gibson HD, DeHaan EN, Alvarez-Hernandez X, Segal RA, Luster AD (2001) SDF-1 alpha induces chemotaxis and enhances Sonic hedgehog-induced proliferation of cerebellar granule cells. Development 128:1971-1981.

Lelievre V, Hu Z, Byun JY, Ioffe Y, Wachek JA (2002) FGF-2 converts PACAP growth action on embryonic hindbrain precursors from stimulation to inhibition. J Neurosci Res 67:566-573.

Lezoualc'h F, Seugnet I, Monnier AL, Ghysdael J, Behr JP, Demeneix BA (1995) Inhibition of neurogenic precursor proliferation by antisense alpha thyroid hormone receptor oligonucleotides. J Biol Chem 270:12100-12108.

Lin X, Bulleit RF (1997) Insulin-like growth factor I (IGF-I) is a critical trophic factor for developing cerebellar granule cells. Brain Res Dev Brain Res 99:234-242.

Lindholm D, Skoglosa Y, Takei N (1998) Developmental regulation of pituitary adenylate cyclase activating polypeptide (PACAP) and its receptor 1 in rat brain: function of PACAP as a neurotrophic factor. Ann NY Acad Sci 865:189-196.

Lu N, DiCicco-Bloom E (1997) Pituitary adenylate cyclase-activating polypeptide is an autocrine inhibitor of mitosis in cultured cortical precursor cells. Proc Natl Acad Sci USA 94:3357-3362.

Lu N, Black IB, DiCicco-Bloom E (1996) A paradigm for distinguishing the roles of mitogenesis and trophism in neuronal precursor proliferation. Brain Res Dev Brain Res 94:31-36.

Lu N, Zhou R, DiCicco-Bloom E (1998) Opposing mitogenic regulation by PACAP in sympathetic and cerebral cortical precursors correlates with differential expression of PACAP receptor (PAC1-R) isoforms. J Neurosci Res 53:651-662.

Lundblad JR, Kwok RP, Laurance ME, Harter ML, Goodman RH (1995) Adenoviral E1A-associated protein p300 as a functional homologue of the transcriptional co-activator CBP. Nature 374:85-88.

Marigo V, Davey RA, Zuo Y, Cunningham JM, Tabin CJ (1996) Bio- 
chemical evidence that patched is the Hedgehog receptor. Nature 384:176-179.

Moro O, Lerner EA (1997) Maxadilan, the vasodilator from sand flies, is a specific pituitary adenylate cyclase activating peptide type I receptor agonist. J Biol Chem 272:966-970.

Morrione A, Romano G, Navarro M, Reiss K, Valentinis B, Dews M, Eves E, Rosner MR, Baserga R (2000) Insulin-like growth factor I receptor signaling in differentiation of neuronal H19-7 cells. Cancer Res 60:2263-2272

Niblock MM, Brunso-Bechtold JK, Riddle DR (2000) Insulin-like growth factor I stimulates dendritic growth in primary somatosensory cortex. J Neurosci 20:4165-4176.

Nicot A, DiCicco-Bloom E (2001) Regulation of neuroblast mitosis is determined by PACAP receptor isoform expression. Proc Natl Acad Sci USA 98:4758-4763.

Nielsen HS, Hannibal J, Fahrenkrug J (1998) Expression of pituitary adenylate cyclase activating polypeptide (PACAP) in the postnatal and adult rat cerebellar cortex. NeuroReport 9:2639-2642.

Pisegna JR, Wank SA (1993) Molecular cloning and functional expression of the pituitary adenylate cyclase-activating polypeptide type I receptor. Proc Natl Acad Sci USA 90:6345-6349.

Pomeroy SL, Tamayo P, Gaasenbeek M, Sturla LM, Angelo M, McLaughlin ME, Kim JY, Goumnerova LC, Black PM, Lau C, Allen JC, Zagzag D, Olson JM, Curran T, Wetmore C, Biegel JA, Poggio T, Mukherjee S, Rifkin R, Califano A, et al (2002) Prediction of central nervous system embryonal tumor outcome based on gene expression. Nature 415:436-442.

Pons S, Trejo JL, Martinez-Morales JR, Marti E (2001) Vitronectin regulates Sonic hedgehog activity during cerebellum development through CREB phosphorylation. Development 128:1481-1492.

Ruiz i Altaba A (1999) Gli proteins and Hedgehog signaling: development and cancer. Trends Genet 15:418-425.

Skoglosa Y, Patrone C, Lindholm D (1999) Pituitary adenylate cyclase activating polypeptide is expressed by developing rat Purkinje cells and decreases the number of cerebellar gamma-amino butyric acid positive neurons in culture. Neurosci Lett 265:207-210.

Smeyne RJ, Chu T, Lewin A, Bian F, S-Crisman S, Kunsch C, Lira SA, Oberdick J (1995) Local control of granule cell generation by cerebellar Purkinje cells. Mol Cell Neurosci 6:230-251.

Solecki DJ, Liu XL, Tomoda T, Fang Y, Hatten ME (2001) Activated Notch2 signaling inhibits differentiation of cerebellar granule neuron precursors by maintaining proliferation. Neuron 31:557-568.

Spengler D, Waeber C, Pantaloni C, Holsboer F, Bockaert J, Seeburg PH, Journot L (1993) Differential signal transduction by five splice variants of the PACAP receptor. Nature 365:170-175.

Stone DM, Hynes M, Armanini M, Swanson TA, Gu Q, Johnson RL, Scott MP, Pennica D, Goddard A, Phillips H, Noll M, Hooper JE, Sauvage FD, Rosenthal A (1996) The tumor-suppressor gene patched encodes a candidate receptor for Sonic hedgehog. Nature 384:129-134.

Suh J, Lu N, Nicot A, Tatsuno I, DiCicco-Bloom E (2001) PACAP is an anti-mitogenic signal in developing cerebral cortex. Nat Neurosci 4:123-124.

Tabuchi A, Koizumi M, Nakatsubo J, Yaguchi T, Tsuda M (2001) In- volvement of endogenous PACAP expression in the activity-dependent survival of mouse cerebellar granule cells. Neurosci Res 39:85-93.

Tao Y, Black IB, DiCicco-Bloom E (1996) Neurogenesis in neonatal rat brain is regulated by peripheral injection of basic fibroblast growth factor (bFGF). J Comp Neurol 376:653-663.

Testaz S, Jarov A, Williams KP, Ling LE, Koteliansky VE, FournierThibault C, Duband JL (2001) Sonic hedgehog restricts adhesion and migration of neural crest cells independently of the PatchedSmoothened-Gli signaling pathway. Proc Natl Acad Sci USA 98: $12521-12526$.

Toftgard R (2000) Hedgehog signalling in cancer. Cell Mol Life Sci 57:1720-1731.

Traiffort E, Charytoniuk D, Watroba L, Faure H, Sales N, Ruat M (1999) Discrete localizations of hedgehog signalling components in the developing and adult rat nervous system. Eur J Neurosci 11:3199-3214.

Vaudry D, Gonzalez BJ, Basille M, Fournier A, Vaudry H (1999) Neurotrophic activity of pituitary adenylate cyclase-activating polypeptide on rat cerebellar cortex during development. Proc Natl Acad Sci USA 96:9415-9420.

Villalba M, Bockaert J, Journot L (1997) Pituitary adenylate cyclaseactivating polypeptide (PACAP-38) protects cerebellar granule neurons from apoptosis by activating the mitogen-activated protein kinase (MAP kinase) pathway. J Neurosci 17:83-90.

Vogel MW, Sunter K, Herrup K (1989) Numerical matching between granule and Purkinje cells in lurcher chimeric mice: a hypothesis for the trophic rescue of granule cells from target-related cell death. J Neurosci 9:3454-3462.

Wallace VA (1999) Purkinje-cell-derived Sonic hedgehog regulates granule neuron precursor cell proliferation in the developing mouse cerebellum. Curr Biol 9:445-448.

Waschek JA (2002) Multiple actions of pituitary adenylyl cyclase activating peptide in nervous system development and regeneration. Dev Neurosci 24:14-23.

Waschek JA, Casillas RA, Nguyen TB, DiCicco-Bloom EM, Carpenter EM, Rodriguez W I (1998) Neural tube expression of pituitary adenylate cyclase-activating polypeptide (PACAP) and receptor: potential role in patterning and neurogenesis. Proc Natl Acad Sci USA 95:9602-9607.

Wechsler-Reya RJ, Scott MP (1999) Control of neuronal precursor proliferation in the cerebellum by Sonic Hedgehog. Neuron 22:103-114.

Wechsler-Reya RJ, Scott MP (2001) The developmental biology of brain tumors. Annu Rev Neurosci 24:385-428.

Wohl CA, Weiss S (1998) Retinoic acid enhances neuronal proliferation and astroglial differentiation in cultures of CNS stem cell-derived precursors. J Neurobiol 37:281-290.

Ye P, Xing Y, Dai Z, D'Ercole AJ (1996) In vivo actions of insulin-like growth factor-I (IGF-I) on cerebellum development in transgenic mice: evidence that IGF-I increases proliferation of granule cell progenitors. Brain Res Dev Brain Res 95:44-54.

Zurawel RH, Allen C, Wechsler-Reya R, Scott MP, Raffel C (2000) Evidence that haploinsufficiency of Patch leads to medulloblastoma in mice. Genes Chromosomes Cancer 28:77-81. 